\title{
Role strain of undergraduate male nurse students during learning experience in nursing education program
}

\author{
Lobna Khamis Mohamed ${ }^{* 1}$, Yosreah Mohamed Mohamed ${ }^{2}$ \\ ${ }^{1}$ Nursing Faculty, Tanta University, Tanta, Egypt \\ ${ }^{2}$ Nursing Faculty, Ain Shams University, Cairo, Egypt
}

Received: October 28, 2014

Accepted: December 4, 2014 Online Published: January 6, 2015

DOI: $10.5430 /$ jnep.v5n3p94

URL: http://dx.doi.org/10.5430/jnep.v5n3p94

\begin{abstract}
Aim: Role strain is one of the concerning issues for male nurse students which indicates increasing evidence for more gender based than their female peers, especially when caring for female patients. The purpose of the current research was to study the role strain of undergraduate male nurse students during their learning experience in nursing education program.

Method: A cross sectional descriptive quantitative design was used in this study. A sample size of 124 and 274 of undergraduates male nurse students were from nursing Faculties of Ain Shams and Tanta Universities respectively. Role strain of male nurse students' questionnaire comprising four subscales; the Community Role Strain (12 items), the Colleague Role Strain (12 items), the Patient Role Strain (7 items), and the Instructors' Role Strain (10 items) was used to assess the role strain of male nurse students during their learning experience in nursing education program.
\end{abstract}

Results: The findings indicated that half of male nurse students had medium level of total role strain. However, the level of total role strain among male nurses' students was higher at Tanta Nursing Faculty than did male students at Ain Shams Nursing Faculty.

Conclusion: There is still much can and should do towards nursing profession to increase the satisfaction of men in nursing. This study provides awareness that important barriers persist for male nursing students in traditional learning environments which is female-oriented.

Key Words: Role strain, Male nurse students, Nursing education program

\section{Introduction}

Despite the constant changes that impact healthcare, the sex imbalance of the nursing education remains constant. ${ }^{[1]}$ Nursing is still does not benefit from men as a potential pool of candidates to ameliorate nursing shortages. ${ }^{[2]}$ Females remain the large majority of students in nursing and of nursing faculty, while males continue to represent only a very small minority in both. In Egypt, male nurses represent just a small fraction of the nursing workforce. ${ }^{[3]}$ For a long time, there were lack of desire and enthusiasm among male students in Egypt to study nursing because of the stigma of nursing profession which may plays one of the major obstacles for choosing nursing career. ${ }^{[1]}$

There are many factors influencing the professional presence of male in nursing to a great extent such as health care needs, nurse's shortage, recruitment and employment chances and the advancement in profession. ${ }^{[4,5]}$ Male nurses are professionals who care the same way as female nurses,

*Correspondence: Lobna Khamis Mohamed; Email: 1kibrahim@ud.edu.sa; Address: Nursing Faculty, Tanta University, Tanta, Egypt. 
however stereotyping them as homosexuals does exist exposing male nurses to homophobia in the workplace. ${ }^{[4]}$ In 2011, the Organization of Men in Nursing Occupations mentioned that men comprised $9 \%$ of all nurses in the United States and $10.2 \%$ of the registered nursing personnel in the United Kingdom. ${ }^{[6]}$ While the Ministry of Health and Population ${ }^{[7]}$ in Egypt stated that men comprised $9.22 \%$ of the registered nursing personnel.

Although the motivations for men and women who enter nursing field are similar like caring, service, and power, but noticeable differences do emerge. ${ }^{[8]}$ But the reasons for the lack of males in the profession were inherent belief in the naturalism of women as nurses, poor working conditions and low pay, inability of males to shake off the low reputation men in nursing had acquired. ${ }^{[9]}$ Although the participation of men in nursing is becoming more acceptable, role strain is one of the issues concerning male nurses which indicating more gender based than do their female peers, especially when caring for female patient. ${ }^{[8]}$

Role strain is a subjective condition, representing an emotional awakening toward impossible role obligations and unease in fulfilling role expectations. It typically occurs due to difficult to exercise the duties of multiple roles and fulfill the required responsibilities. ${ }^{[10]}$ For various reasons, the expectations associated with a role may be mutually incompatible or undesirable, leaving male nurse students with feelings of discomfort to fulfill role obligations due to unaccepting the underlying values that justify the expectations in an undesirable manner or at an unavailable time. ${ }^{[1]}$

Males experience psychological pressure to conform to stereotyped expectations about their role. ${ }^{[12,13]}$ Men who fail to conform may experience role strain which implicit and explicit through disapproval from members of the community (family, general public), from colleagues at work, from instructors and from patients. ${ }^{[14]}$

Little amount of researches focused upon the kinds of role strain experienced by men in female-dominated professions. Encouraging male students to study nursing without addressing and studying the stigmatizing factors form barriers for their career. Therefore, it is necessary to understand the role strain experienced by male nursing students during their attending of learning experience in nursing education to assist in finding ways to reduce it and increase number of men in nursing.

\subsection{Aim of the study}

The purpose of the current research was to study the role strain of undergraduate male nurse students during their learning experience in nursing education.

\subsection{Research questions}

Three research's questions were asked about:
(1) What is role strain for undergraduates' male nurse students during their attending of learning experience in nursing eduation?

(2) Is there any relation between undergraduates' male nursing students' demographic characteristics and their experience of role strain?

\section{Material and methods}

\subsection{Design}

A cross sectional descriptive quantitative design was used to answer the research's questions under this study.

\subsection{Setting}

This study was conducted at Nursing Faculties of both Ain Shams and Tanta Universities.

\subsection{Sample}

A sample size of 124 and 274 undergraduates male nurse students were from nursing Faculties of Ain Shams and Tanta Universities respectively which included all available male nurse students who accepted to participate in the study.

All students who consented to participate in writing filled in a self-administered questionnaire in the presence of the researcher. The inclusion criteria for selection of sampling were logically based upon male undergraduate nurse students in first, second, third and fourth year at the end of second semester of academic year 2013/2014. Students were assured that no penalty would arise from withdrawal or nonparticipation.

\subsection{Tools}

This tool developed by the researchers to study the role strain was facing male nurse students during their attending of learning experience in nursing education program which resulting from their perception of incompatibility between their roles as nurses and their roles as males as seen by the members of community, colleagues, patients and instructors. It consisted of two parts as follows:

The first part involved socio-demographic data of the subjects as: their age, academic year, residence, marital status, pre-university qualifications, and place of training in undergraduates' clinical area, as well as willingness to enter Faculty of Nursing, academic achievement in previous year and which department preferred to work in after graduation.

The second part of this tool was developed based on literature of O'Lynn ${ }^{[15]}$ and MacWilliams et al. ${ }^{[16]}$ It consisted of four sections in 41 items. The first section was the Community Role Strain (12 items) which arises from negative attitudes of persons outside the nursing field, such as family members and general public. The second section was Colleague Role Strain (12 items) which arises from the attitudes 
and behaviors of female counterparts, friends in and outside the field. The third section was Patient Role Strain (7 items) which considered the attitudes of patients and their families toward male nurse students. The fourth section was Instructors' Role Strain (10 items) which considered the attitudes of nurse educators toward male nurse students in theoretical and clinical learning environment of nursing education.

The researchers used test-retest reliability of nominal data which its value was identical resulting in Kendall's tau and Spearman's rho both equal 1. Cronbach's coefficient alpha was used to measure internal consistency reliability of questionnaire which greater than 0.7 .

\subsection{Methods}

Based on revision of data from panel of 5 experts from different nursing departments of Nursing Faculties at Tanta and Ain Shams Universities, a pilot study was carried out on 5\% of undergraduates' male nursing students (excluded from study sampling). Additional modifications were made to the instruments. The questionnaire sheet consumed about 5-10 minutes to be answered, and collection period was extended for a period of two months and half started at the beginning of April to half of June.

\subsection{Ethical consideration}

The data was collected after the approval from the authoritative personnel of Nursing Faculties at Tanta and Ain Shams Universities. Prior to the data collection, participants were informed about the purpose of the research and were obtained an oral informed consent. They were assured that data collection was only being done on a voluntary basis and answers were kept confidential.

\subsection{Statistical analysis}

All Data was collected, tabulated and subjected to statistical analysis. Statistical analysis was performed by SPSS in general (version 17), also Microsoft Office Excel was used for data handling and graphical presentation. Quantitative variables were described by the Mean, Standard Deviation $(S D)$, while qualitative categorical variables were described by proportions and percentages. Analyzed data was done through the use of two tests; student $t$-test and ANOVA Spearman's rho which used to measure correlation. Significance level stated at $p<.05$, while $p<.01$ was considered highly significant.

\section{Results}

The total number of male nursing students was 398, representing $95 \%$ response rate from both settings. Responses from 4 participants were eliminated due to major blanks left in the questionnaire.

Table 1 shows socio-demographic data of male nurse students at Tanta and Ain Shams Nursing Faculties. At Tanta 96
Nursing Faculty, $62.4 \%$ were in age group 20 to 21 years, $35.8 \%$ were in third academic year, $62.4 \%$ were from rural areas, $97.8 \%$ were single, $87.2 \%$ were graduated from secondary school, $42.7 \%$ were trained in nursing administration department, $47.1 \%$ had very good as academic achievement, $62.0 \%$ were "unwilling" to enter nursing field, and $24.8 \%$ were preferred to work in psychiatric nursing after graduation.

Regarding Ain Shams Nursing Faculty, 49.2\% were in age group 20 to 21 years, $40.3 \%$ were in first academic year, $58.1 \%$ were from urban areas, all of them were single, $84.7 \%$ were graduated from secondary school, $70.2 \%$ were trained in nursing administration department, $42.3 \%$ had very good as academic achievement, $66.9 \%$ were "willing" to enter nursing field, and $28.2 \%$ were preferred to work in administration position after graduation.

Table 2 reveals the comparison of role strain means scores among male nursing students at Tanta and Ain Shams Nursing Faculties. Male students at Tanta Nursing Faculty had significantly higher mean scores than did male students at Ain Shams Nursing Faculty in four role strain subscales (Patients, Colleagues, Instructors and Community). The highest mean score was patients' role strain $(65.64 \pm 17.99$ \& 58.70 \pm 17.76$)$ followed by colleagues role strain at work $(62.56 \pm 13.57 \& 58.14 \pm 12.03)$, then instructors role strain at clinical learning environment $(60.94 \pm 17.01 \&$ $54.44 \pm 16.69)$ and after that members of community role strain $(57.31 \pm 15.86 \& 48.28 \pm 12.78)$ for male students at Tanta and Ain Shams respectively.

Figure 1 represents levels of total role strain among male nursing students at Tanta and Ain Shams Nursing Faculties. In general, around half of male nurse students had medium level of total role strain regardless of subscales in both settings at Tanta and Ain Shams Nursing Faculties. Regarding the higher role strain, the male nurse students at Tanta had a higher percentage $(26.3 \%)$, while male nurse students at Ain Shams had a considerable lower percent (7.3\%). For the lower role strain, the students at Ain Shams had a higher percentage $(37.1 \%)$, while the students at Tanta had a lower percentage $(14.2 \%)$.

Table 3 describes the relationship between demographic data of male nursing students and their perceived role strain subscales at Tanta and Ain Shams Nursing Faculties. This table suggested statistical significant correlations between age of participants with their perceived patients' $(r=0.134$ $\& p<.02)$ and instructors' $(r=0.207 \& p<.001)$ role stain subscales at Tanta Nursing Faculty, as well as with community $(r=.243 \& p<.006)$, colleagues $(r=.231 \& p<.010)$ and instructors $(r=.337 \& p<.000)$ role strain subscale at Ain Shams Nursing Faculty. In relation for academic year, there were statistical significant effect with all role stain subscales except for community strain at Tanta, as well as for colleagues and patient strain at Ain Shams.

ISSN 1925-4040 E-ISSN 1925-4059 
Table 1: Socio-demographic data of male nursing students at Tanta and Ain Shams Nursing Faculties

\begin{tabular}{|c|c|c|c|c|c|c|}
\hline \multirow[t]{2}{*}{ Data Variables } & \multicolumn{2}{|c|}{$\begin{array}{l}\text { Tanta Nursing Faculty } \\
(\mathrm{n}=274)\end{array}$} & \multicolumn{2}{|c|}{$\begin{array}{l}\text { Ain Shams Nursing Faculty } \\
(\mathrm{n}=124)\end{array}$} & \multicolumn{2}{|c|}{ Total } \\
\hline & No. & $\%$ & No. & $\%$ & No. & $\%$ \\
\hline \multicolumn{7}{|l|}{ Age (Years) } \\
\hline $18-19$ & 54 & 19.7 & 39 & 31.5 & 93 & 23.4 \\
\hline $20-21$ & 171 & 62.4 & 61 & 49.2 & 232 & 58.3 \\
\hline $22-23$ & 49 & 17.9 & 24 & 19.4 & 73 & 18.3 \\
\hline \multicolumn{7}{|l|}{ Academic year } \\
\hline First & 64 & 23.4 & 50 & 40.3 & 114 & 28.6 \\
\hline Second & 75 & 27.4 & 37 & 29.8 & 112 & 28.1 \\
\hline Third & 98 & 35.8 & 17 & 13.7 & 115 & 28.9 \\
\hline Fourth & 37 & 13.5 & 20 & 16.1 & 57 & 14.3 \\
\hline \multicolumn{7}{|l|}{ Residence } \\
\hline Urban & 103 & 37.6 & 72 & 58.1 & 175 & 44.0 \\
\hline Rural & 171 & 62.4 & 52 & 41.9 & 223 & 56.0 \\
\hline \multicolumn{7}{|l|}{ Marital status } \\
\hline Single & 268 & 97.8 & 124 & 100.0 & 392 & 98.5 \\
\hline Married & 6 & 2.2 & 0 & 0.0 & 6 & 1.5 \\
\hline \multicolumn{7}{|l|}{ Pre-university qualification } \\
\hline Secondary School & 239 & 87.2 & 105 & 84.7 & 344 & 86.4 \\
\hline Health Technical Institute & 22 & 8.0 & 6 & 4.8 & 28 & 7.0 \\
\hline Nursing Technical Institute & 13 & 4.7 & 13 & 10.5 & 26 & 6.5 \\
\hline \multicolumn{7}{|l|}{ Training place } \\
\hline Nursing Administration & 117 & 42.7 & 87 & 70.2 & 204 & 51.3 \\
\hline Medical-surgical & 34 & 12.4 & 5 & 4.0 & 39 & 9.8 \\
\hline Obstetric & 35 & 12.8 & 5 & 4.0 & 40 & 10.1 \\
\hline Pediatric & 46 & 16.8 & 13 & 10.5 & 59 & 14.8 \\
\hline Community & 26 & 9.5 & 2 & 1.6 & 28 & 7.0 \\
\hline Psychiatry & 6 & 2.2 & 12 & 9.7 & 18 & 4.5 \\
\hline Fundamental & 10 & 3.6 & 0 & 0.0 & 10 & 2.5 \\
\hline \multicolumn{7}{|c|}{ Previous academic achievement } \\
\hline Excellent & 71 & 25.9 & 16 & 13.0 & 87 & 21.9 \\
\hline Very good & 129 & 47.1 & 52 & 42.3 & 181 & 45.6 \\
\hline Good & 53 & 19.3 & 44 & 35.8 & 97 & 24.4 \\
\hline Pass & 18 & 6.6 & 9 & 7.3 & 27 & 6.8 \\
\hline Fail & 3 & 1.1 & 2 & 1.6 & 5 & 1.3 \\
\hline \multicolumn{7}{|c|}{ Willingness to enter nursing field } \\
\hline Yes & 104 & 38.0 & 83 & 66.9 & 187 & 47.0 \\
\hline No & 170 & 62.0 & 41 & 33.1 & 211 & 53.0 \\
\hline \multicolumn{7}{|c|}{$\begin{array}{l}\text { Preferred department want to work in } \\
\text { after graduation }\end{array}$} \\
\hline Nursing administration & 53 & 19.3 & 35 & 28.2 & 88 & 22.1 \\
\hline Psychiatric & 68 & 24.8 & 22 & 17.7 & 90 & 22.6 \\
\hline Pediatric & 46 & 16.8 & 17 & 13.7 & 63 & 15.8 \\
\hline Obstetric & 25 & 9.1 & 14 & 11.3 & 39 & 9.8 \\
\hline Medical & 36 & 13.1 & 14 & 11.3 & 50 & 12.6 \\
\hline Surgical & 6 & 2.2 & 19 & 15.3 & 25 & 6.3 \\
\hline Emergency & 40 & 14.6 & 3 & 2.4 & 43 & 10.8 \\
\hline
\end{tabular}

Table 2: Comparison of role strain means scores among male nursing students at Tanta and Ain Shams Nursing Faculties

\begin{tabular}{lllll}
\hline Role strain subscales & Tanta Nursing Faculty & Ain Shams Nursing Faculty & \multirow{2}{*}{-test } & $\boldsymbol{p}$ \\
\hline Community Role Strain Scale (Com.RS) & $57.31 \pm 15.86$ & $48.28 \pm 12.78$ & 5.57 & $.0000^{* * *}$ \\
Colleagues' Role Strain Scale (Col. RS) & $62.56 \pm 13.57$ & $58.14 \pm 12.03$ & 3.11 & $.0019^{* * *}$ \\
Patients' Role Strain Scale (PRS) & $65.64 \pm 17.99$ & $58.70 \pm 17.76$ & 3.58 & $.0003^{* * *}$ \\
Instructors' Role Strain Scale (IRS) & $60.94 \pm 17.01$ & $54.44 \pm 16.69$ & 3.55 & $.0004^{* * *}$ \\
Total Role Strain & $61.61 \pm 12.56$ & $54.89 \pm 10.29$ & 5.22 & $.0000^{* * *}$ \\
\hline
\end{tabular}

$P<.001^{* * *}$ Highly Significant 


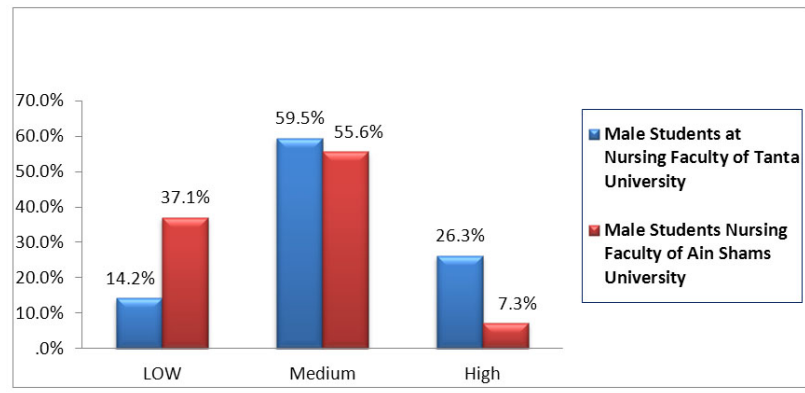

Figure 1: Total strain levels of male nursing students at Tanta and Ain Shams Nursing Faculties

Moreover, there were statistical significant effect of partic- ipants' training place on colleagues and patient strain $(f=$ $3.32, p<.003 \& f=2.82, p<.011)$ at Tanta respectively, as well as with community and instructors strain $(f=2.75, p<$ $.022 \& f=5.72, p<.000)$ at Ain Shams respectively. There were highly significant effect of male students' willingness to enter nursing field on community strain $(t=5.86, p<.000$ $\& t=3.77, p<.000)$ at Tanta and Ain Shams respectively.

No statistical significant effect between participants' residence area, academic achievement and pre-university qualification with their perceived role strain subscales in both settings. While there was a significant effect of participants' preference for working in department after graduation on instructors' role strain $(f=2.42, p<.030)$ at Ain Shams.

Table 3: Relationship between demographic data of male nursing students and their perceived role strain subscales at Tanta and Ain Shams Nursing Faculties

\begin{tabular}{|c|c|c|c|c|c|c|c|c|c|c|}
\hline \multirow{2}{*}{\multicolumn{2}{|c|}{ Demographic variables }} & \multirow{4}{*}{$\begin{array}{l}\text { Test } \\
r \\
p\end{array}$} & \multicolumn{4}{|c|}{ Tanta Nursing Faculty } & \multicolumn{4}{|c|}{ Ain Shams Nursing Faculty } \\
\hline & & & \multirow{3}{*}{$\begin{array}{l}\begin{array}{l}\text { Com. } \\
\text { RS }\end{array} \\
-.035 \\
.569\end{array}$} & \multirow{3}{*}{$\begin{array}{l}\begin{array}{l}\text { Col. } \\
\text { RS }\end{array} \\
0.088 \\
.147\end{array}$} & \multirow{3}{*}{$\begin{array}{l}\begin{array}{l}\text { Pat. } \\
\text { RS }\end{array} \\
0.134 \\
.027^{*}\end{array}$} & \multirow{3}{*}{$\begin{array}{l}\text { Ins. RS } \\
0.207 \\
.001^{* *}\end{array}$} & \multirow{3}{*}{$\begin{array}{l}\text { Com. RS } \\
0.243 \\
.006^{* *}\end{array}$} & \multirow{3}{*}{$\begin{array}{l}\begin{array}{l}\text { Col. } \\
\text { RS }\end{array} \\
0.231 \\
.010^{* *}\end{array}$} & \multirow{3}{*}{$\begin{array}{l}\text { Pat. } \\
\text { RS } \\
0.085 \\
.350\end{array}$} & \multirow{3}{*}{$\begin{array}{l}\text { Ins. RS } \\
0.337 \\
.000^{* * *}\end{array}$} \\
\hline & & & & & & & & & & \\
\hline Age & & & & & & & & & & \\
\hline $\begin{array}{l}\text { Academic } \\
\text { year }\end{array}$ & $\begin{array}{l}\text { First } \\
\text { Second } \\
\text { Third } \\
\text { Fourth }\end{array}$ & $\begin{array}{l}f \\
p\end{array}$ & $\begin{array}{l}1.94 \\
.123\end{array}$ & $\begin{array}{l}3.35 \\
.019^{*}\end{array}$ & $\begin{array}{l}4.40 \\
.004^{* *}\end{array}$ & $\begin{array}{l}6.55 \\
.000^{* * * *}\end{array}$ & $\begin{array}{l}3.67 \\
.014^{*}\end{array}$ & $\begin{array}{l}2.41 \\
.070\end{array}$ & $\begin{array}{l}1.84 \\
.143\end{array}$ & $\begin{array}{l}7.36 \\
.000^{* * *}\end{array}$ \\
\hline Residence & $\begin{array}{l}\text { Urban } \\
\text { Rural }\end{array}$ & $\begin{array}{l}t \\
p\end{array}$ & $\begin{array}{l}1.35 \\
.178\end{array}$ & $\begin{array}{l}-0.88 \\
.377\end{array}$ & $\begin{array}{l}-1.37 \\
.171\end{array}$ & $\begin{array}{l}-1.09 \\
.274\end{array}$ & $\begin{array}{l}-0.33 \\
.739\end{array}$ & $\begin{array}{l}1.42 \\
.157\end{array}$ & $\begin{array}{l}2.44 \\
.056\end{array}$ & $\begin{array}{l}0.05 \\
.956\end{array}$ \\
\hline $\begin{array}{l}\text { Pre-university } \\
\text { qualification }\end{array}$ & $\begin{array}{l}\text { Secondary School } \\
\text { Health Technical Ins. } \\
\text { Nursing Technical Ins. }\end{array}$ & $\begin{array}{l}f \\
p\end{array}$ & $\begin{array}{l}2.62 \\
.074\end{array}$ & $\begin{array}{l}0.53 \\
.590\end{array}$ & $\begin{array}{l}1.25 \\
.289\end{array}$ & $\begin{array}{l}0.35 \\
.708\end{array}$ & $\begin{array}{l}1.04 \\
.355\end{array}$ & $\begin{array}{l}0.74 \\
.479\end{array}$ & $\begin{array}{l}0.02 \\
.983\end{array}$ & $\begin{array}{l}0.55 \\
.577\end{array}$ \\
\hline Training place & $\begin{array}{l}\text { Administration } \\
\text { Medical-surgical } \\
\text { Obstetric } \\
\text { Pediatric } \\
\text { Community } \\
\text { Psychiatry } \\
\text { Fundamental }\end{array}$ & $\begin{array}{l}f \\
p\end{array}$ & $\begin{array}{l}1.42 \\
.205\end{array}$ & $\begin{array}{l}3.32 \\
.003^{* *}\end{array}$ & $\begin{array}{l}2.82 \\
.011^{*}\end{array}$ & $\begin{array}{l}2.08 \\
.056\end{array}$ & $\begin{array}{l}2.75^{*} \\
.022\end{array}$ & $\begin{array}{l}1.16 \\
.333\end{array}$ & $\begin{array}{l}1.59 \\
.167\end{array}$ & $\begin{array}{l}5.72 \\
.000^{* * *}\end{array}$ \\
\hline $\begin{array}{l}\text { Previous } \\
\text { academic } \\
\text { achievement }\end{array}$ & $\begin{array}{l}\text { Excellent } \\
\text { Very good } \\
\text { Good } \\
\text { Pass } \\
\text { Fail }\end{array}$ & $\begin{array}{l}f \\
p\end{array}$ & $\begin{array}{l}1.63 \\
.166\end{array}$ & $\begin{array}{l}1.38 \\
.242\end{array}$ & $\begin{array}{l}1.40 \\
.233\end{array}$ & $\begin{array}{l}2.34 \\
.055\end{array}$ & $\begin{array}{l}1.40 \\
.236\end{array}$ & $\begin{array}{l}1.20 \\
.313\end{array}$ & $\begin{array}{l}2.20 \\
.073\end{array}$ & $\begin{array}{l}0.44 \\
.782\end{array}$ \\
\hline $\begin{array}{l}\text { Willingness to } \\
\text { enter Nursing }\end{array}$ & $\begin{array}{l}\text { Yes } \\
\text { No }\end{array}$ & $\begin{array}{l}t \\
p\end{array}$ & $\begin{array}{l}5.86 \\
.000^{* * * *}\end{array}$ & $\begin{array}{l}-1.06 \\
.291\end{array}$ & $\begin{array}{l}0.34 \\
.735\end{array}$ & $\begin{array}{l}-0.31 \\
.755\end{array}$ & $\begin{array}{l}3.77 \\
.000^{* * *}\end{array}$ & $\begin{array}{l}-0.69 \\
.491\end{array}$ & $\begin{array}{l}-0.46 \\
.643\end{array}$ & $\begin{array}{l}-2.03 \\
.044\end{array}$ \\
\hline $\begin{array}{l}\text { Preferred } \\
\text { department } \\
\text { want to work } \\
\text { in after } \\
\text { graduation }\end{array}$ & $\begin{array}{l}\text { Nursing admin. } \\
\text { Psychiatric } \\
\text { Pediatric } \\
\text { Obstetric } \\
\text { Medical } \\
\text { Surgical } \\
\text { Emergency }\end{array}$ & $\begin{array}{l}f \\
p\end{array}$ & $\begin{array}{l}0.97 \\
.443\end{array}$ & $\begin{array}{l}1.18 \\
.315\end{array}$ & $\begin{array}{l}1.74 \\
.111\end{array}$ & $\begin{array}{l}1.22 \\
.296\end{array}$ & $\begin{array}{l}0.36 \\
.904\end{array}$ & $\begin{array}{l}0.48 \\
.822\end{array}$ & $\begin{array}{l}0.38 \\
.892\end{array}$ & $\begin{array}{l}2.42 \\
.030^{*}\end{array}$ \\
\hline
\end{tabular}

Note. $r$ = Correlation coefficients, $t=$ Student $t$-test, $f=$ ANOVA $F$-test $p<.001 * * *$ Highly Significant, $p<.01^{* *}$ Significant, $p>.01^{*}$ Not Significant

Table 4 illustrates correlation between perceived role strain subscales at Tanta and Ain Shams Nursing Faculties. It revealed highly statistical significant correlations between all perceived role strain subscales among male nurse students at both Tanta and Ain Shams Nursing Faculties. 
Table 4: Correlation between perceived role strain subscales at Tanta and Ain Shams Nursing Faculties

\begin{tabular}{|c|c|c|c|c|c|c|}
\hline \multirow[b]{2}{*}{ Role Strain Subscales } & \multicolumn{3}{|c|}{ Tanta Nursing Faculty } & \multicolumn{3}{|c|}{ Ain Shams Nursing Faculty } \\
\hline & $\begin{array}{l}\text { Coll. Role } \\
\text { Strain }\end{array}$ & $\begin{array}{l}\text { Pat. Role } \\
\text { Strain }\end{array}$ & $\begin{array}{l}\text { Ins. Role } \\
\text { Strain }\end{array}$ & $\begin{array}{l}\text { Coll. Role } \\
\text { Strain }\end{array}$ & $\begin{array}{l}\text { Pat. Role } \\
\text { Strain }\end{array}$ & $\begin{array}{l}\text { Ins. Role } \\
\text { Strain }\end{array}$ \\
\hline Com. Role Strain & $0.485^{* *}$ & $0.425^{* *}$ & $0.233^{* *}$ & $0.305^{* *}$ & $0.281^{* *}$ & $0.432^{* *}$ \\
\hline Coll. Role Strain & & $0.564^{* *}$ & $0.426^{* *}$ & & $0.318^{* *}$ & $0.434^{* *}$ \\
\hline Pat. Role Strain & & & $0.501^{* *}$ & & & $0.351^{* *}$ \\
\hline
\end{tabular}

** Correlation Coefficients

\section{Discussion}

In fact, Egypt is a male dominant culture and nursing is primarily a female dominant profession which practiced by women, while males who are practicing nursing are very few. This may be the reason for male students to see nursing as a female profession and find role strain during their learning of nursing program. Therefore the aim of this research is to study the role strain of undergraduate male nurse students during their learning experience in nursing education.

The results of this study showed that male nurse students mainly wanted to work in psychiatric nursing field at Tanta and occupy administrative positions at Ain Shams after graduation. This finding is in same line with the Kloster et al. [17] and Stott ${ }^{[18]}$ who claimed that males tended to choose "less intimate" specialization areas such as administration, anesthetics and psychiatric nursing in order to cope with role strain in a female dominated profession. In contrast to this finding Dyck ${ }^{[19]}$ reported that female students wanted to see males in staff nurse positions.

In this study, the findings revealed four role strain experienced by undergraduates' male nurse students during their learning in nursing education program at Tanta and Ain Shams Nursing Faculties. Accordingly, the male students were ranked the patients' role strain as the most important barrier followed by colleagues' role strain at work, then instructors' role strain at clinical learning environment and after those members of community role strain.

In this aspect, Kirk et al. ${ }^{[20]}$ identified many barriers for male students during their learning in two different programs of nursing; the men rated the online program significantly more accepting of their gender based barriers than their traditional campus programs.

In the current study, it can be noticed that male nurse students who are engaged in the study of nursing in both settings agreed that patients' role strain is the most important source of stress during nursing learning. Participants reported feeling of being unwelcome in clinical learning environment; fearing of suspect touch when providing care for female patients and withholding significant personal information by them. Another aspect of role strain comes from female and male patients who generally prefer female nurses. This finding is consistent with the claim of Hood ${ }^{[21]}$ who stated that males are sometimes still not accepted by certain patient groups, who still adhere to false stereotypes of males in nursing.

The study findings found that male students were very anxious regarding colleagues' role strain at work. Participants suggested that many female nurses resent working with them, see them as muscle, and consider them a threat to their profession. The majority of male students pointed out that absence of male nurses in clinical learning environment is a source of dissatisfaction and many female nurses believe male nurses should care for only male patients. Study findings were similar to that reported by Liang et al. ${ }^{[22]}$ in which the main barrier for male nurse students was colleagues' resistance which discourage men from becoming nurses.

With regard to role strain experienced from contacts with instructors at clinical learning environment, the male nurse students considered it as one of the major reasons that put them under stress. Study's results revealed that the sexrelated bias in obstetric rotations, lack of nursing programs to prepare men to work primarily with women and lack of male faculty staff or practicing male nurses in clinical learning environment are the most sources of instructors' role strain as reported by the male students. Another aspect of instructors' role strain comes from little or no course content on men's contribution to nursing and no/little recognition received from instructors in clinical learning environment.

Consistently with the current findings, Bell-Scriber ${ }^{[23]}$ mentioned that the textbooks didn't represent male and female nurses equally, especially the pediatric and mental health nursing textbooks. All of pictures and stories about nurses used female examples. Moreover, Wilson ${ }^{[9]}$ suggested that tendency of nursing academics to generalize nursing in the context of the female gender, including males in discussions as an afterthought.

Grady et al. ${ }^{[24]}$ in this aspect concluded that faculty members have a responsibility to assist all students in the caring aspects of the profession regardless of gender; faculty have a fundamental and immediate influence on the beliefs, attitudes, and behaviors of students. On the other hand, Moore $^{[25]}$ study revealed that more male instructors could alleviate much of the conflict experienced by the male students in their study. More importantly, Wilson ${ }^{[9]}$ identified a lack of support from the faculty as a primary reason why 
men leave nursing programs.

Moreover, male students experienced community role strain as a source of stress. Male students strongly agreed that the word "nurse" referred to "she not he", working in nursing is time consuming and if they have sons, they will advise them to avoid nursing career, as well as when they first introduced to other men or women, they hesitate to identify themselves as nurses. Hood ${ }^{[21]}$ suggested that the word "nurse" still carries a strong gender stereotype in our society due to the gender bias in nursing recruitment advertisements. Eswi and El Sayed ${ }^{[26]}$ research confirmed the previous finding and claimed that Egyptian male students nurse considered societal image of nursing profession as one of the major reasons which put them under stress and lead to the sense of inferiority and embarrassment. Wang et al. ${ }^{[27]}$ stated that male students encountered social pressure. It is still not widely socially acceptable for men to enter the nursing profession in China.

Based on the results of this study, the major finding was around half of male nurse students had mild role strain in both settings of study. It was surprising that participants would not suffer as much of role strain between their gender identity and their occupational role. The explanation for lack of severe role strain among male nurse students may be due to the propensity of men in nursing to seek out new background about masculinity within the nursing profession which minimize role strain. This finding was supported by Stott $^{[18]}$ result which revealed that male students had only mild role strain.

On the contrary, Bartfay et al. ${ }^{[28]}$ suggested that male nurse students experienced high level of role strain and anxiety. Moore $^{[25]}$ also found that role strain was a common stressor for many men in female dominant careers due to the tension between gender role and career identity.

In general, the level of total role strain among male nurse students was higher at Tanta Nursing Faculty than did male students at Ain Shams Nursing Faculty with highly statistical significant differences in four role strain subscales (patients, colleagues, instructors and community). McMillian et al. ${ }^{[29]}$ explained the possible reason for this finding may be due to male nurse students growing up in rural settings during critical developmental periods might have more traditional background and attitudes towards gender when compared with those growing up in urban settings.

The current Findings documented statistical significant correlations between age of participants with their perceived patients' and instructors' role stain subscales at Tanta Nursing Faculty, as well as with community, colleagues and instructors role strain at Ain Shams Nursing Faculty. This means that older male students had more strain for patients and instructors at Tanta, while they had more strain for community, colleagues and instructors at Ain Shams. Generally, these results may be due to increasing their maturity and understanding by their age.

There were statistical significant effect between academic year of male nurse students and all role stain subscales except for community strain at Tanta, as well as for colleagues and patient strain at Ain Shams. Moreover, there were a statistical significant effect of participants' training place on colleagues' and patients' strain at Tanta, as well as with community and instructors strain at Ain Shams.

Results indicated highly significant effect of male nurse students' willingness to enter nursing field on community role strain at Tanta and Ain Shams. This finding was not surprising because most of male students in both settings faced more stress when choosing nursing as a career due to inherent beliefs of nursing field from community members. While a significant effect was present of participants' preference for working in department after graduation on instructors' role strain at Ain Shams. This means that the instructors played an important role on male nurse students' preference for choosing the department they will work in after graduation.

Results indicated no statistical significant effect of participants' residence area, academic achievement and preuniversity qualification on their perceived role strain subscales in both settings. In view of this, the recent study of Robert and his colleagues ${ }^{[30]}$ stated no statistical significant correlation between demographic data of male nurse students and confronted role strain during nursing program. He explained this finding may be due to role strain among male nursing students takes a variety of forms.

Based upon these current findings, there are highly statistical significant correlations between all subscales of role strain at Tanta and Ain Shams Nursing Faculties. All male nurse students in both settings view the perceived role strain as significant barriers during their learning experience in nursing education program.

\section{Limitation of the study}

The current study was exploratory in nature and localized in two faculties of nursing only which mean that the findings of this study can't be generalized, so that it should be applied in different Egyptian Nursing Faculties.

\section{Conclusion}

The present study concluded that role strain is mild among male nurse students generally, but it isn't mean to deny the reality of the problems they may experience from patients, their colleagues, instructors and members of the community. The level of total role strain among male nurses' students was higher at Tanta Nursing Faculty than did male students at Ain Shams Nursing Faculty. The current study documented that only five variables of demographic data namely, 
respondents' age, academic year, training place, willingness to enter nursing and preferred work department, significantly predict the role strain toward male nurse students during their learning in nursing education program.

Based on findings of the current study, the researchers recommended greater efforts and actions to create positive male role models in academia and clinical practice. These actions include increasing awareness of community regarding nursing as an appropriate profession for both sexes; and improving nursing image through public media. Developing strategies which allow male faculty staff to visit male secondary schools to change their attitudes towards nursing profession. Creating a friendly learning environment on the nursing faculty and updating the nursing curriculum to be learner-centered which supports the needs of all students for both sexes without gender bias. Really, there is still much can and should do towards nursing profession to increase the satisfaction of men in nursing.

\section{Conflicts of Interest Disclosure}

The author declares that there is no conflict of interest statement.

\section{References}

[1] Keogh B, O’Lynn C. Male Nurses' Experiences of Gender Barriers Irish and American Perspectives. Nurse Educator. 2007; 32(6) 256-9. PMid:17998853 http://dx.doi.org/10.1097/01. NNE. 0000299478.64809 .82

[2] McLaughlin K, Muldoon O, Moutray M. Gender, Gender Roles and Completion of Nursing Education: A longitudinal study. Nurse Education Today. 2010; 30(4): 303-7. PMid:19758730 http://dx.d oi.org/10.1016/j.nedt.2009.08.005

[3] Mohamed HE, El- Nemer AM. The Experience of Newly Enrolled Egyptian Male Nursing Students into Maternity Nursing Curriculum. Life Science Journal. 2013; 10(1): 2810-5.

[4] Williams D. Recruiting men into nursing school. 2006; Available from: http://www.minoritynurse.com/article/recr uiting-men-nursing-school

[5] Tracey C, Nicholl $\mathrm{H}$. The multifaceted influence of gender in career progress in nursing. Journal of Nursing Management. 2007; 15(7): 677-82. PMid: 17897143 http://dx.doi.org/10.1111/j $.1365-2934.2006 .00677 . x$

[6] Men in Nursing Occupations. 2011; Available from: http://www. census.gov/newsroom/releases/pdf/cb1 332_men_in_nursing_occupations.pdf

[7] Ministry of Health and Population, Egypt. 2008; Available from: http://www.mohp.gov.eg/default.aspx

[8] Yaling T, Chen J, Tu Hsiu-C, et al. Role strain of different gender nursing students in obstetrics practice: a comparative study. Journal of Nursing Research. 2009; 17(1): 1-9. PMid:19352224 http://dx.doi.org/10.1097/JNR. 0b013e3181999b85

[9] Wilson G. The experience of males entering nursing: A phenomenological analysis of professionally enhancing factors and barriers. Contemporary Nurse. 2005; 20: 221-233. PMid:16393104 http: //dx.doi.org/10.5172/conu.20.2.221

[10] Chen JY, Huang CC, Liu YY. Developing Instruments to Assess Role Strain in Nursing Students. Global Advanced Research Journal of Educational Research and Review. 2014; 3(1): 12-21.

[11] Marietta JB. Warming the nursing education climate for traditional - age learners who are male. Nursing Education Perspectives. 2008; 29(3): 143-51.

[12] Chen JY. Morale and Job-related strain of undergraduate nursing students in a pediatric clinical setting. J. Nursing Res. 2010; 18(2): 144-153. PMid:20592660 http://dx.doi.org/10.1097/JNR . 0 b013e3181e365a0

[13] Abdel El-Halem GE, El Hawashy ZI, Gamal El-Dein AA, et al. Undergraduate Male Nursing students' Perception about the Image of the Nursing Profession. Journal of American Science. 2011; 7(3): 614-24.

[14] Khamis L, El-Sayed KA. Junior Undergraduates Nurse Students' Images of Nursing as a Career Choice. Journal of American Science. 2013; 9(12): 25-34. Avaliable from: http://www.jof americanscience.org/journals/am-s ci/am0912/005_21169am0912_25_34.pdf
[15] O'Lynn CE. Gender-based barriers for male students in nursing education programs prevalence and percieved importance. Journal of Nursing Education. 2004; 43(5): 229-36. PMid: 15152800

[16] MacWilliams BR, Schmidt B, Bleich MR. Men in Nursing: Understanding the challenges men face working in this predominantly female profession AJN. 2013; 113(1): 38-44.

[17] Kloster T, Høie M, Skar R. Nursing students' career preferences: a Norwegian study. Journal of Advanced Nursing. 2007; 59(2): 155-62. PMid:17484741 http://dx.doi.org/10.1111/j.136 5-2648.2007.04276.x

[18] Stott A. Issues in the socialization process of the male Student nurse: implications for retention in undergraduate nursing courses. Nurse Education Today. 2004; 24: 91-7. PMid:14769452 http: //dx.doi.org/10.1016/j.nedt.2003.09.005

[19] Dyck JM, Oliffe J, Phinney A, et al. Nursing instructors' and male nursing students' perceptions of undergraduate, classroom nursing education. Nurse Education Today. 2009; 29: 64953. PMid:19269071 http://dx.doi.org/10.1016/j.nedt.20 09.02 .003

[20] Kirk JR, O’Lynn CE, Ponton MK. Perceptions of gender-based barriers for men in an online nursing completion program compared to traditional on-campus nursing programs. MERLOT Journal of Online Learning and Teaching. 2013; 9(4): 481-88.

[21] Hood P. Life as a male nurse. Registered Nurse Journal. 2002; 65(2): 37-8.

[22] Liang Y, Xiao D, Cai Y, et al. Survey of demands of male nurses in hospital. Nanfang Journal of Nursing. 2004; 11-3. PMid:15331169

[23] Bell-Scriber MJ. Warming the nursing education climate for traditional-age learners: who are male. Nursing Education Perspectives. 2008; 29(3): 134-50.

[24] Grady CA, Stewardson GA, Hall JL. Faculty notions regarding caring in male nursing students. Journal of Nursing Education. 2008; 47(1): 314-23. PMid:18630717 http://dx.doi .org/10.3928/0 1484834-20080701-05

[25] Moore GA, Dienemann JA. Job satisfaction and career development of men in nursing. Journal of Nursing Education and Practice. 2014; 4(3): 86-93. http://dx.doi.org/10.5430/jnep.v4n3p86

[26] Eswi A, El Sayed Y. The experience of Egyptian male student nurses during attending maternity nursing clinical course. Nurse Education in Practice. 2010: 1 - 6.

[27] Wang H, Li X, Hu X, et al. Perception of Nursing Profession and Learning Experiences of Male Students in baccalaureate nursing program in Changsha, China. Nurse Education Today. 2010; 36-42. PMid:20392548

[28] Bartfay WJ, Bartfay E, Clow KA. Attitudes and perception towards men in nursing education. The internet Journal of Allied Health Sciences of Practice. 2010; 8(2): 1-7.

[29] McMillian J, Morgan SA, Ament P. Acceptance of Male Registered Nurses by Female Registered Nurses. Journal of Nursing Scholarship. 2006; 38(1): 100-6. PMid:16579331 http://dx. doi .org/1 $0.1111 / j .1547-5069.2006 .00066 . x$

[30] Robert MB, Bonnie S, Michael B. Men in Nursing: Understanding the challenges men face working in this predominantly female profession. American Journal of Nursing. 2013; 113(1): 38-44. 